\title{
Education Research: Teaching and assessing communication and professionalism in neurology residency with simulation
}

Arielle M. Kurzweil, MD, Ariane Lewis, MD, Perrin Pleninger, MD, Sara K. Rostanski, MD, Aaron Nelson, MD, Cen Zhang, MD, Sondra Zabar, MD, Koto Ishida, MD, Laura J. Balcer, MD, MSCE, and Steven L. Galetta, MD

Neurology ${ }^{\circledR} 2020 ; 94: 229-232$. doi:10.1212/WNL.0000000000008895

\author{
Correspondence \\ Dr. Kurzweil \\ arielle.kurzweil@ \\ nyulangone.org
}

In medical education, professionalism and interpersonal communication skills are considered to be equally important to the mastery of medical fund of knowledge. ${ }^{1,2}$ The American Association of Medical Colleges states that "medical schools should articulate and defend the importance of professional values," and suggests tools for developing and assessing these skills, such as 360-degree evaluations, simulations, clinical vignettes, retreats, and focus groups. ${ }^{1}$ The Accreditation Council for Graduate Medical Education includes interpersonal communication and professionalism as core competencies; trainees must achieve these before practicing independently. ${ }^{2}$

This emphasis on professionalism and communication competencies may be related to data showing a link between excellence in communication skills and improved medical outcomes. Such outcomes include increased patient satisfaction and trust, increased patient adherence with treatments, increased likelihood patients will stay with a physician, fewer patient complaints, and reductions in the frequency of litigation. ${ }^{3}$ Furthermore, unprofessional behavior is associated with reduced productivity among colleagues, high physician turnover, and propensity for physician burnout. ${ }^{4}$

Despite their importance, the best methods for teaching professionalism and communication skills remain unclear. We sought to (1) assess the self-reported comfort level of neurology residents with professionalism and communication tasks; (2) identify how neurology residents feel that they learn best; (3) explore faculty's perception of teaching residents about professionalism and communication; and (4) pilot a novel educational initiative to improve professionalism and communication skills for our residents.

\section{Methods}

Anonymous electronic surveys were distributed to neurology residents and faculty in the Department of Neurology at our institution in October 2017. Surveys were designed to assess perceptions regarding resident education on interpersonal communication and professionalism tasks, including specific scenarios such as breaking bad news, delivering a sensitive diagnosis, discussing prognosis, leading a goals-of-care discussion, disclosing a medical error, reviewing risks and benefits of IV tissue plasminogen activator (tPA), and communicating with members of the care team (see supplemental data, links.lww.com/WNL/B39). After review of the survey results, a committee of faculty members and residents discussed how to improve resident education about communication and professionalism. Due to the study's design, review by the institutional review board was waived.

Based on survey results (discussed in the following section), we designed a program of performance-based assessment to augment our existing didactic on professionalism and 
communication that takes place during summer orientation to our program. A simulation curriculum including observation and feedback of 8 objective structured clinical examinations (OSCEs) to be conducted over the course of neurology training at our New York Simulation Center was developed. The curriculum included cases addressing the following tasks: performing a handoff with a coresident, consenting a patient for IV tPA, working with a difficult colleague, identifying an impaired coresident, disclosing a medical error to a patient, discussing prognosis with a patient's family member, giving and receiving feedback from a medical student, and informing a patient that he or she has a functional neurologic problem. A neurology faculty member worked with experienced medical education simulation faculty to develop a script and casespecific checklist items. The core communication behavioral anchored checklist aligned with other graduate medical education programs at our institution. For each case, a standardized professional (SP) was trained to play the role of a colleague, senior faculty member, medical student, patient, or patient's family member.

During the OSCEs, residents are told about their role and the task for each case through a document posted on the door of the simulation rooms. After entering the room, residents are given 10 minutes to complete the task. A neurology faculty member observes each OSCE, then provides 5 minutes of verbal feedback. Each SP completes a behavioral anchored checklist for each resident documenting professionalism and interpersonal communication skills. At the end of the OSCEs, faculty members lead a 30-minute debriefing session during which residents discuss their experience and review take-away pearls.

\section{Results}

\section{Survey results}

The survey was completed by 20 out of 42 residents and 73 out of 125 faculty members. Of the 20 residents, 50\% were female; $80 \%$ were adult neurology residents, $15 \%$ were neurology/psychiatry residents, and 5\% were child neurology residents; $45 \%$ were postgraduate year 4, 30\% were postgraduate year 2 , and $25 \%$ were postgraduate year 3 . Of the 73 faculty, $47 \%$ were female; $37 \%$ attended for 0-3 weeks of inpatient consult/service time annually, 36\% attended 4-8 weeks annually, 17\% attended 9-15 weeks annually, and 10\% attended more than 15 weeks annually; $50 \%$ were faculty at our institution for less than 5 years, $21 \%$ were faculty at our institution for 5-10 years, and 29\% were faculty at our institution for 11 or more years.

Although no residents endorsed being very uncomfortable performing any of the interpersonal communication and professionalism tasks assessed in the survey, only 1 resident (5\%) endorsed feeling very comfortable performing all the tasks. Fewer than $50 \%$ of residents noted that a faculty member had observed them performing the majority of these tasks, and fewer than $30 \%$ of residents reported that they had ever been given feedback on their performance of each of these tasks (figure, $\mathrm{A}$ and $\mathrm{B}$ ).

Although only $6 \%$ of faculty reported they never taught residents about any of the interpersonal communication and professionalism tasks listed in the survey, for every task included in the survey, fewer than $50 \%$ of faculty indicated that they had observed residents performing the task and fewer than $50 \%$ indicated that they had provided feedback to residents about the task (figure, A and B).

When asked about the perceived effectiveness of different modes of teaching, $100 \%$ of residents indicated that doing a task was an effective means of learning extremely often/very often and $95 \%$ of residents reported that observing an attending perform a task is an effective means of learning extremely often/very often. A total of $65 \%$ reported that didactics were an effective means of learning extremely often/ very often and $40 \%$ said reading a textbook about a task was effective extremely often/very often.

\section{Programmatic evaluation of performance- based assessment}

As of March 2018, we have run each set of OSCEs twice. Based on feedback from anonymous surveys, the 57 residents who participated in the OSCEs agreed the OSCE cases were similar to real-life encounters (mean score 4.1/5 [with 5 being strongly agree and 1 being strongly disagree]), but were neutral about whether their performance on OSCEs adequately reflected their performance in practice (mean 3.4/5). The residents believed the OSCEs were very useful (mean score $4.7 / 5$, with 5 being most useful). When asked if each OSCE should be repeated for future classes, with the exception of 1 resident who said maybe for 1 OSCE, $100 \%$ of residents indicated yes for every OSCE.

\section{Discussion}

Building a comprehensive simulation curriculum to address interpersonal communication skills and professionalism is feasible and beneficial to neurology residents and faculty. There are many known benefits to incorporating simulation into residency education. Simulations provide a safe environment for practicing skills, enable a uniform experience for all, allow residents to interact with reliable and readily available "patients," and help build a culture of safety. ${ }^{5}$ Over the last 10 years, neurology residencies have been utilizing simulation to enforce principles for managing acute stroke, ${ }^{6}$ to train residents to perform lumbar punctures, 7 and to teach residents about direct ophthalmoscopy. ${ }^{8}$ There is a dearth of literature suggesting use of a simulation center for developing professionalism and interpersonal communication skills, particularly in neurology residency. Nonetheless, simulation can positively affect physician performance and clinical outcomes, as has been demonstrated with screening for high-risk behaviors, ${ }^{9}$ safer opioid prescribing practices, ${ }^{10}$ and assessing pain. ${ }^{11}$ 

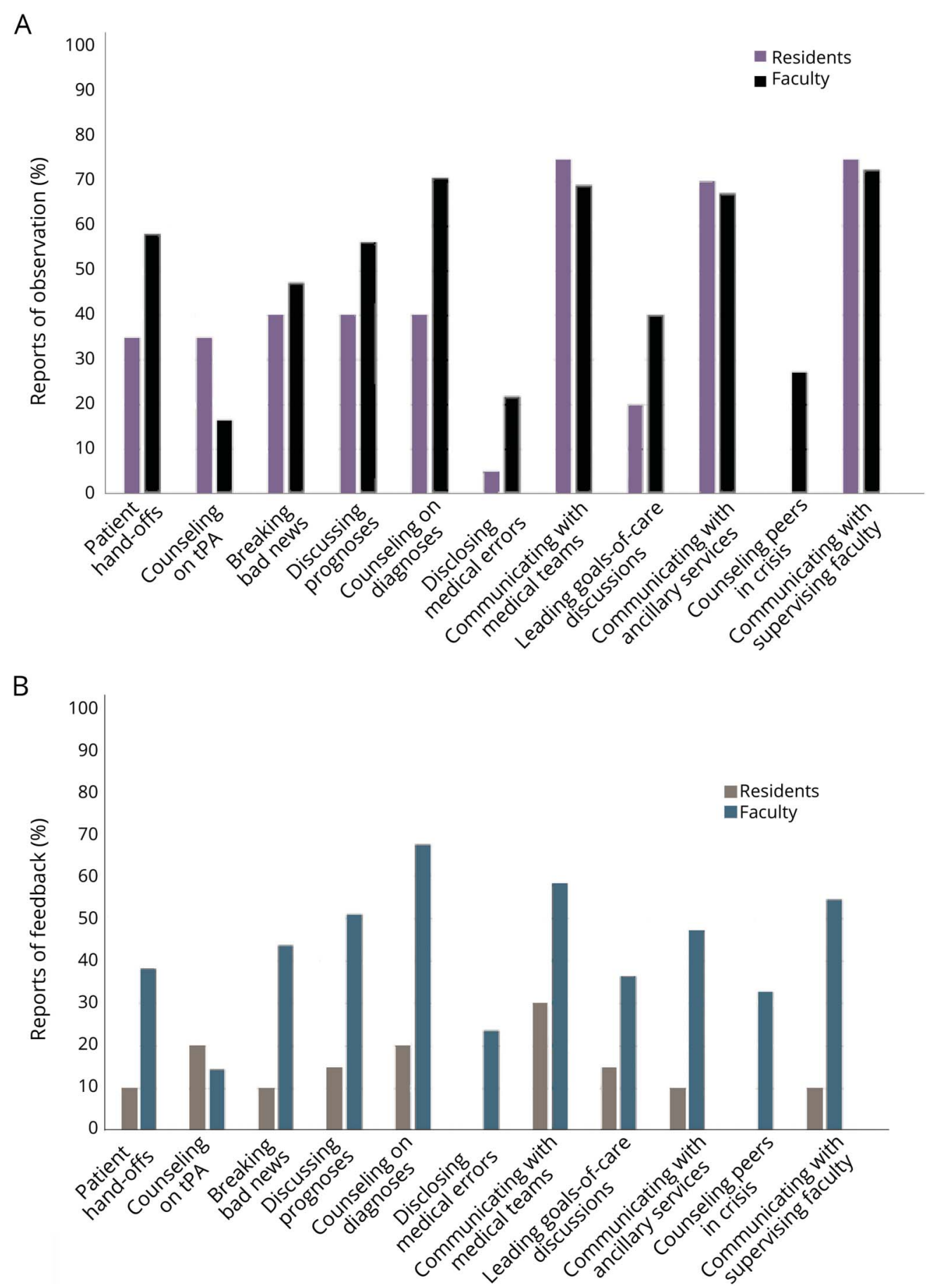

(A) Resident and faculty report of observation while performing interpersonal communication and professionalism tasks during clinical rotations. (B) Resident and faculty report of feedback to residents regarding interpersonal communication and professionalism tasks during clinical rotations. tPA = tissue plasminogen activator.

Our survey results demonstrate that the traditional method of teaching through apprenticeship, a format whereby we hope that faculty exhibit professional behavior with good communication and that trainees model this behavior, may not be adequate. Furthermore, this method does not provide a standardized, uniform experience for each resident, especially when there is a large number of trainees and faculty.
Our residents desired more frequent feedback than our faculty appreciated. Through the simulation curriculum we implemented, professionalism and communication skills can be observed and assessed in real time followed by immediate, specific feedback for improvement. Residents believed, on the whole, that the OSCEs were useful, and should be repeated for future training classes. 
We hope that describing this intervention will be beneficial for neurology resident education at other institutions. We recognize that it will not be feasible for all residency programs to implement this type of curriculum, as it requires both access to and the financial means to work with a simulation center and faculty availability to create and observe the OSCEs.

We acknowledge that surveys have limitations due to their subjective nature. Further study of this curriculum is needed to assess potential effect on resident performance and clinical outcomes over time. Many residents in our program have anecdotally reported utilizing skills developed during the OSCEs during their clinical rotations. We plan to survey our residents more formally on perceived effect of the OSCEs on their skills. Continued implementation of the simulation curriculum and assessment of its effect is needed to create a standardized approach to interpersonal communication and professionalism education in neurology residency programs.

\section{Author contributions}

A. M. Kurzweil: drafting/revising the manuscript, data acquisition, study concept or design, analysis or interpretation of data, accepts responsibility for conduct of research and final approval, acquisition of data, statistical analysis, study supervision. A. Lewis: drafting/revising the manuscript, data acquisition, study concept or design, accepts responsibility for conduct of research and final approval. P. Pleninger: drafting/revising the manuscript, study concept or design, accepts responsibility for conduct of research and final approval, acquisition of data, study supervision. Sara Kate Rostanski: drafting/revising the manuscript, accepts responsibility for conduct of research and final approval, acquisition of data. A. Nelson: drafting/revising the manuscript, data acquisition, study concept or design, analysis or interpretation of data, accepts responsibility for conduct of research and final approval, acquisition of data, statistical analysis, study supervision. C. Zhang: drafting/ revising the manuscript, data acquisition, study concept or design, accepts responsibility for conduct of research and final approval. S. Zabar: drafting/revising the manuscript, study concept or design, analysis or interpretation of data, accepts responsibility for conduct of research and final approval, acquisition of data. K. Ishida: drafting/revising the manuscript, data acquisition, accepts responsibility for conduct of research and final approval, acquisition of data. L. J. Balcer: drafting/revising the manuscript, analysis or interpretation of data, accepts responsibility for conduct of research and final approval. Steven Galetta: drafting/revising the manuscript, study concept or design, analysis or interpretation of data, accepts responsibility for conduct of research and final approval.

\section{Study funding}

No targeted funding reported.

\section{Disclosure}

The authors report no disclosures relevant to the manuscript. Go to Neurology.org/N for full disclosures.

\section{References}

1. AAMC. Assessment of Professionalism Project [online]. Available at: aamc.org/ download/77168/data/professionalism.pdf. Accessed March 15, 2019.

2. ACGME. ACGME Milestones Guidebook [online]. Available at: acgme.org/Portals/ 0/PDFs/Milestones/MilestonesGuidebookforResidentsFellows.pdf. Accessed March 15, 2019.

3. Reed DA, West CP, Mueller PS, Ficalora RD, Engstler GJ, Beckman TJ. Behaviors of highly professional resident physicians. JAMA 2008;300:1326.

4. Mareiniss DP. Decreasing GME training stress to foster residents' professionalism. Acad Med 2004;79:825-831.

5. Issenberg SB, Scalese RJ. Simulation in health care education. Perspect Biol Med 2007;51:31-46.

6. Mehta T, Strauss S, Beland D, Fortunato G, Staff I, Lee N. Stroke simulation improves acute stroke management: a systems-based practice experience. J Grad Med Educ 2018;10:57-62.

7. Sun C, Qi X. Evaluation of problem- and simulator-based learning in lumbar puncture in adult neurology residency training. World Neurosurg 2018;109: e807-e811.

8. Gupta DK, Khandker N, Stacy K, Tatsuoka CM, Preston DC. Utility of combining a simulation-based method with a lecture-based method for fundoscopy training in neurology residency. JAMA Neurol 2017;74:1223-1227.

9. Zabar S, Hanley K, Stevens DL, et al. Can interactive skills-based seminars with standardized patients enhance clinicians' prevention skills? Measuring the impact of a CME program. Patient Educ Couns 2010;80:248-252.

10. Roy P, Jackson AH, Baxter J, et al. Utilizing a faculty development program to promote safer opioid prescribing for chronic pain in internal medicine resident practices. Pain Med 2019;20:707-716.

11. Stevens DL, King D, Laponis R, et al. Medical students retain pain assessment and management skills long after an experiential curriculum: a controlled study. Pain $2009 ; 145: 319-324$.

\section{AAN Online Learning Center}

Browse a variety of online CME, self-assessment, and other learning activities to suit your wide-ranging interests and learning styles. Visit Learning.AAN.com today to access the Online Learning Center, your exclusive member-only hub for AAN continuing medical education. 


\section{Neurology}

\section{Education Research: Teaching and assessing communication and professionalism in neurology residency with simulation}

Arielle M. Kurzweil, Ariane Lewis, Perrin Pleninger, et al.

Neurology 2020;94;229-232 Published Online before print January 20, 2020

DOI 10.1212/WNL.0000000000008895

This information is current as of January 20, 2020

\section{Updated Information \&} Services

References

Citations

Subspecialty Collections

Permissions \& Licensing

Reprints including high resolution figures, can be found at: http://n.neurology.org/content/94/5/229.full

This article cites 9 articles, 0 of which you can access for free at: http://n.neurology.org/content/94/5/229.full\#ref-list-1

This article has been cited by 2 HighWire-hosted articles: http://n.neurology.org/content/94/5/229.full\#\#otherarticles

This article, along with others on similar topics, appears in the following collection(s):

\section{All Education}

http://n.neurology.org/cgi/collection/all_education

Methods of education

http://n.neurology.org/cgi/collection/methods_of_education

Professional conduct and ethics

http://n.neurology.org/cgi/collection/professional_conduct_and_ethics

Information about reproducing this article in parts (figures,tables) or in its entirety can be found online at:

http://www.neurology.org/about/about_the_journal\#permissions

Information about ordering reprints can be found online:

http://n.neurology.org/subscribers/advertise

Neurology ${ }^{\circledR}$ is the official journal of the American Academy of Neurology. Published continuously since 1951, it is now a weekly with 48 issues per year. Copyright (C 2020 American Academy of Neurology. All rights reserved. Print ISSN: 0028-3878. Online ISSN: 1526-632X.

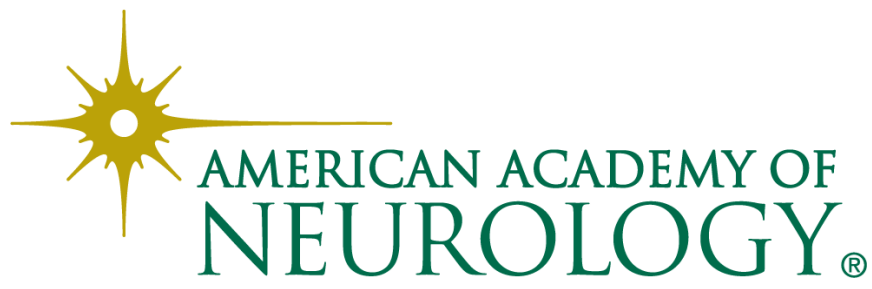

